\title{
Problem-oriented Management of United Territorial Communities' Development Based on Decentralization under the Pandemic Influence
}

\author{
Yuriy Ivanov ${ }^{1}$, Olga Ivanova ${ }^{1 *}$, Viacheslav Laptiev ${ }^{2}$ Olga Polyakova ${ }^{1}$, and Viktoriia \\ Shlykova ${ }^{1}$ \\ ${ }^{1}$ Research Center for Industrial Development Problems National Academy of Sciences of Ukraine, \\ Sector of Macroeconomic Analysis and Forecasting, Department of Macroeconomic Policy and \\ Regional Development, 61145 Kharkiv, Ukraine \\ ${ }^{2}$ Simon Kuznets Kharkiv National University of Economics, Department of Social Economics, 61145 \\ Kharkiv, Ukraine
}

\begin{abstract}
The article is devoted to the problem-oriented management of spatial development of united territorial communities (UTC) under the conditions of decentralization under the influence of economic consequences of the Covid-19 pandemic. The article aims to justify the problem-oriented approach in the management of UTC based on the development of a cognitive map of the problems of their development and modelling the problem-oriented management of community resources on the example of human resources. The problem-oriented approach to resource management focuses on solving a problem as a specific theoretical or practical problem, which in turn adaptability, flexibility, the ability to make timely management decisions using available resources. The cognitive map of the four groups of problems of UTC development was developed: problems of the spatial development of UTC and administrative-territorial structure; problems of socio-economic development based on selfsufficiency; problems of local self-government system; problems of rural territories development. The example of human resources scenarios of problem-oriented management of community resources at the macro-, meso-; micro-levels were offered. The hypothesis that the effect of measures "from below" will spread more rapidly than "from above" has been proved. Keywords: problem-oriented management, united territorial communities (UTC), problem-oriented approach, administrative-territorial structure.
\end{abstract}

The impact of the pandemic on the development of countries and their territorial units, entrepreneurship, and the development of human resources in general leads to two polar trends. On the one hand, these are the negative effects of Covid-19 on all spheres of life, associated with economic consequences for territorial communities, regions, businesses, unemployment for human resources. On the other hand, these are new opportunities for growth and development at all economic levels, which must be used to improve the competitiveness of all subjects.

* Corresponding author: laptevaou@gmail.com 
Another problem in the development of united territorial communities is their formation as separate independent units, which are capable of self-development, but have many barriers: the distribution of authorities between the centre and united territorial communities, as well as responsibilities; problems of sufficient resource provision of self-development of territorial communities; insufficient level of skills of territorial communities management staff to develop effective strategies and development programs, real development projects, etc.

All this requires the introduction of an adaptive methodology in the united territorial communities development in a pandemic, which is based on a problem-oriented approach.

The article aims to justify the problem-oriented approach in the management of united territorial communities based on the development of a cognitive map of the problems of their development, as well as modelling the problem-oriented management of community resources on the example of human resources.

The economic crisis caused by Covid-19 changed the way of life and consumption of the population. Also, quarantine restrictions caused the transformation of economic players' behaviour in the production and consumption market on the principles of uncertainty and limitation. Both the pandemic and quarantine measures led to a slowdown in the economies of the world and Ukraine as well (Fig. 1) [1]. This negatively affects the economic security of countries and their sustainable economic development [2].

Change in GDP,

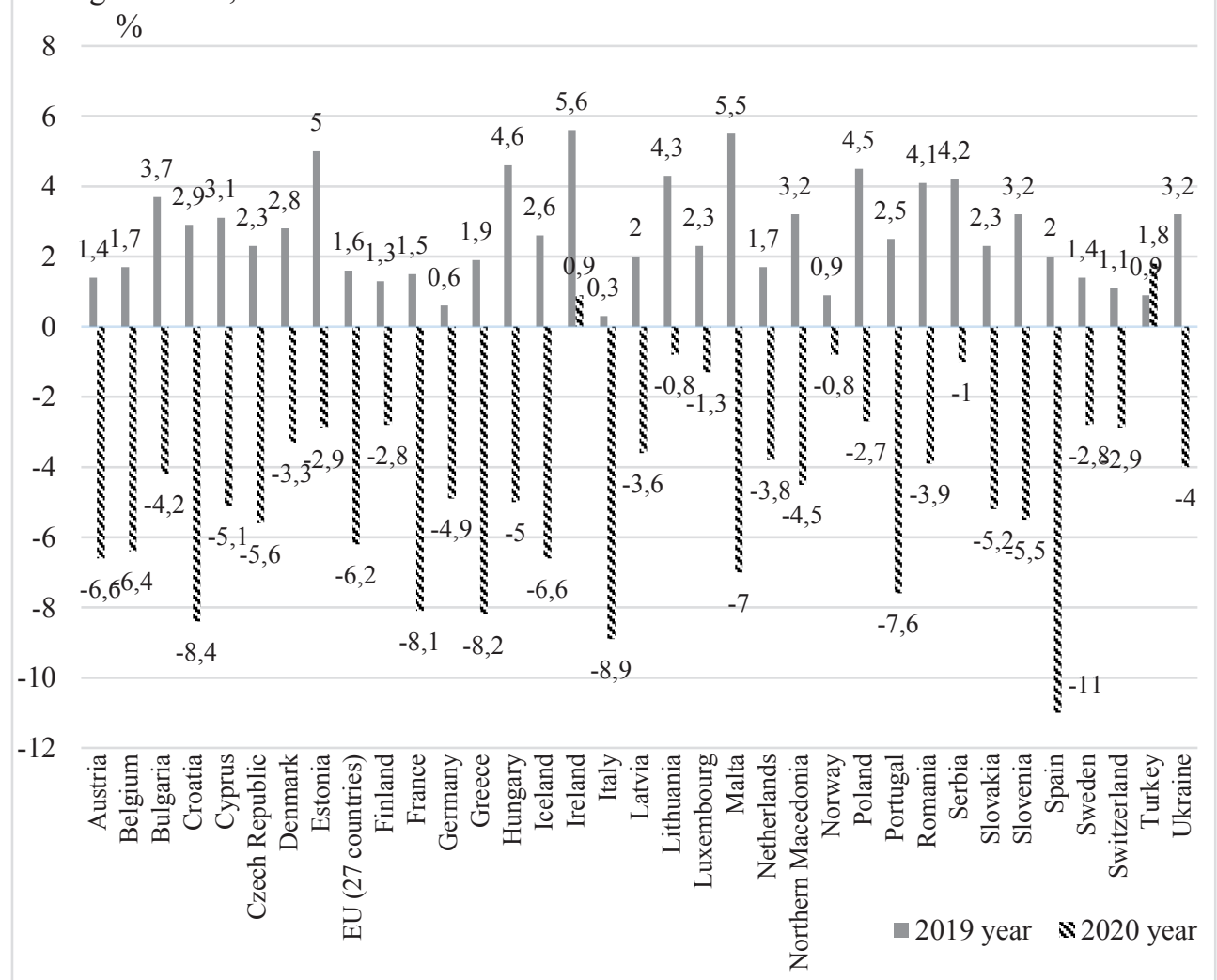

Fig. 1. Change in GDP in Ukraine and EU countries to the corresponding period of the previous year, $\%$ 
The rate of GDP decrease is directly related to the negative consequences of the pandemic, so the most significant negative indicators are observed in Spain (11\%), Italy (8.9\%), Greece (8.2\%), and Croatia (8.4\%). In Ukraine, this indicator reached $4 \%$ due to the transformational nature of the economy, a large share of agriculture, poorly developed tourism, weak involvement in the production chains of added value in the global economy. Ukraine in 2020 showed fewer negative rates and better indicators of GDP dynamics than Hungary and Slovakia, which had a deeper recession than Ukraine at the end of the year.

The country's socio-economic development and regions depend on the possibility of territorial units of self-development based on resource self-sufficiency. Processes of reformation of economic and political processes in Ukraine occur under the influence of European integration [3]. It requires the development of reanimation measures to ensure sustainable social and economic development of regions based on the improvement of state and local resources management system in the sphere of tax [4] and budget relations between the centre and communities [5] human resources, etc.

Decentralization reform in Ukraine is a prerequisite for successfully implementing reforms in other spheres of territorial community development. However, its successful implementation requires the contribution of human resources.

The problem-oriented approach to resource management is "this approach focuses on solving a problem as a specific theoretical or practical problem, which in turn implies adaptability, flexibility, the ability to make timely management decisions using available resources [6]. Consequently, under the conditions of the decentralization reform, the application of this approach makes it possible to identify problems during the implementation of the reform and to involve effective methods and mechanisms of united territorial communities' development management of the executive authorities, public, business and population of the region to solve them.

Implementation of the problem-oriented approach requires identifying problems of united territorial communities' development based on decentralization under the pandemic influence.

According to the results of the survey by Swiss-Ukrainian Decentralization Support Project DESPRO [7] and the Ukrainian Association of united territorial communities [8] in $2020,46 \%$ of respondents noted the suspension of small and medium-sized businesses in united territorial communities (UTC) as a result of quarantine measures, $52 \%$ noted the social responsibility of business in the fight against the pandemic, the focus on new consumer needs $(21 \%)$ and the shift to telecommuting (55\%). The situation of unemployment in the UTC by respondents is noted as critical because of the quarantine (57\%), $44 \%$ of the residents of the UTC note the critical level of financial security, enough only for necessities [9].

Among the main challenges to local self-governance authorities and obstacles to development that befell Ukrainian territorial communities under the conditions of decentralization of power are the following groups of problems (Fig. 2):

1) problems of the spatial development of UTC and administrative-territorial structure: the lack of clearly substantiated criteria of unification of territorial communities; high fragmentation of administrative-territorial units of local level; unresolved issues of territorial planning and formation of general plans;

2) Problems of socio-economic development based on self-sufficiency: legislative failure to regulate the functioning of local Government on the distribution of powers, resources; low level of quality of life in the communities; low level of financial capacity of united territorial communities about delegated powers. Quarantine and suspension of work of many enterprises through COVID-19 caused problems in the economic sphere and affected the financial capacity of united territorial communities. 


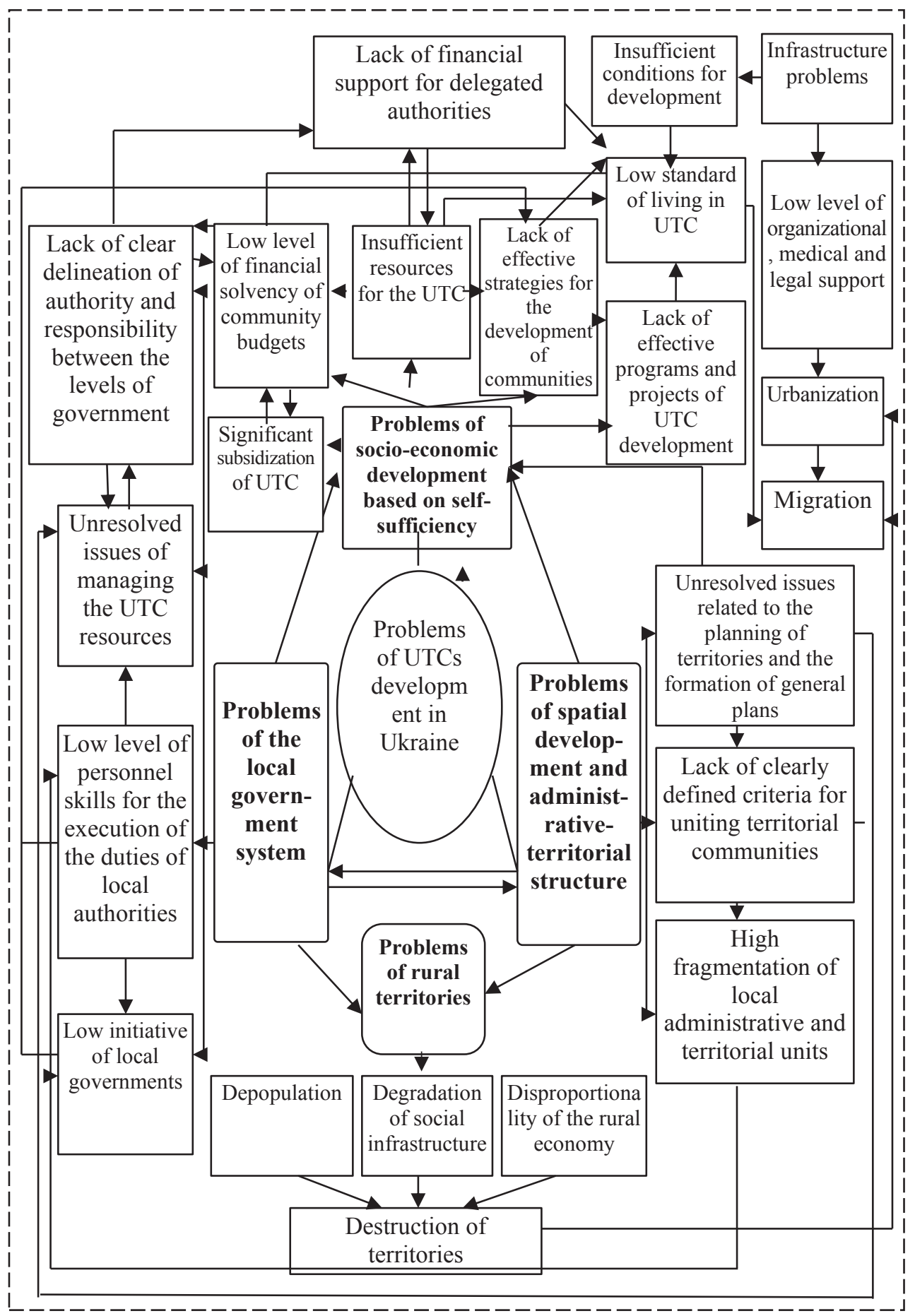

Inconsistency and lack of a complete legal framework for the development of UTCs

Fig. 2. Cognitive map of the relationship between the problems of the spatial development of UTCs 
Because of the structure of own revenues of local budgets (approximately $95 \%$ of them are tax revenues, the benefits of which are offered to businesses in the regions) these budgets of territorial communities suffer significant losses. Thus, losses of regions due to anti-crisis measures proposed by the Government, according to the Open Budget portal and experts in financial and local budget management of DOBRE/USAID programs [10; 11], will amount to approximately $2-3 \%$ of tax revenues of general funds of local budgets in 2020 ;

$3)$ problems of the local self-government system: low level of training, competence, awareness of personnel for the implementation of the powers of local self-government, human resources of territorial communities, lack of experience in negotiation, search for compromise and consensus, lack of systemic understanding of the process may hinder the cooperation of UTC for joint development, etc.;

4) problems of rural development economic problems caused by the specifics of rural UTC, inefficient methods of farming in rural areas; outdated material base, structural disproportions of production.

For effective implementation of reforms on decentralization, the human (in this case, staff) potential of local self-governments should be activated to form and implement appropriate mechanisms for coordination of territorial bodies of executive power. We are talking about self-governance as the ability of local governments to manage processes based on creating effective mechanisms for managing social relations in the region and ensuring effective interaction between subjects in the chain of relations "state-region-business-public" to ensure long-term socio-economic development of the region.

In order to model the scenarios, a simulation model of problem-oriented human resource development in Vensim was built (Fig. 3).

The indicators of the effectiveness of the proposed scenarios are the performance indicators: the value of the indicators of GDP per person, GRP per person, labour productivity; staff turnover; a number of persons who improved their qualifications

To identify the most effective options for the development of human resources at three economic levels, the following scenarios are considered:

- scenario 1 - "optimistic -1", which includes variables at the macro level: government spending on education and training (direct costs); expansion of the tax credit for individual entrepreneurs who are not the flat taxpayers, and expanding the list of services to include advanced training and retraining of both entrepreneurs themselves and their employees;

- scenario 2 - "optimistic-2", - changes in the costs of education and training programs for the development of human resources at the regional level and united territorial communities;

- scenario 3 - "optimistic-3" - management due to additional costs of enterprises for personnel [12].

Four scenarios were considered to identify the most effective options for human resources development at the three economic levels: the baseline scenario - unchanged indicators of problem-oriented human resource development at all economic levels (Table 1).

Each scenario has associated risks that need to be considered in the model. It is also essential to formulate criteria for the effectiveness of human resource development in terms of qualitative and quantitative parameters 


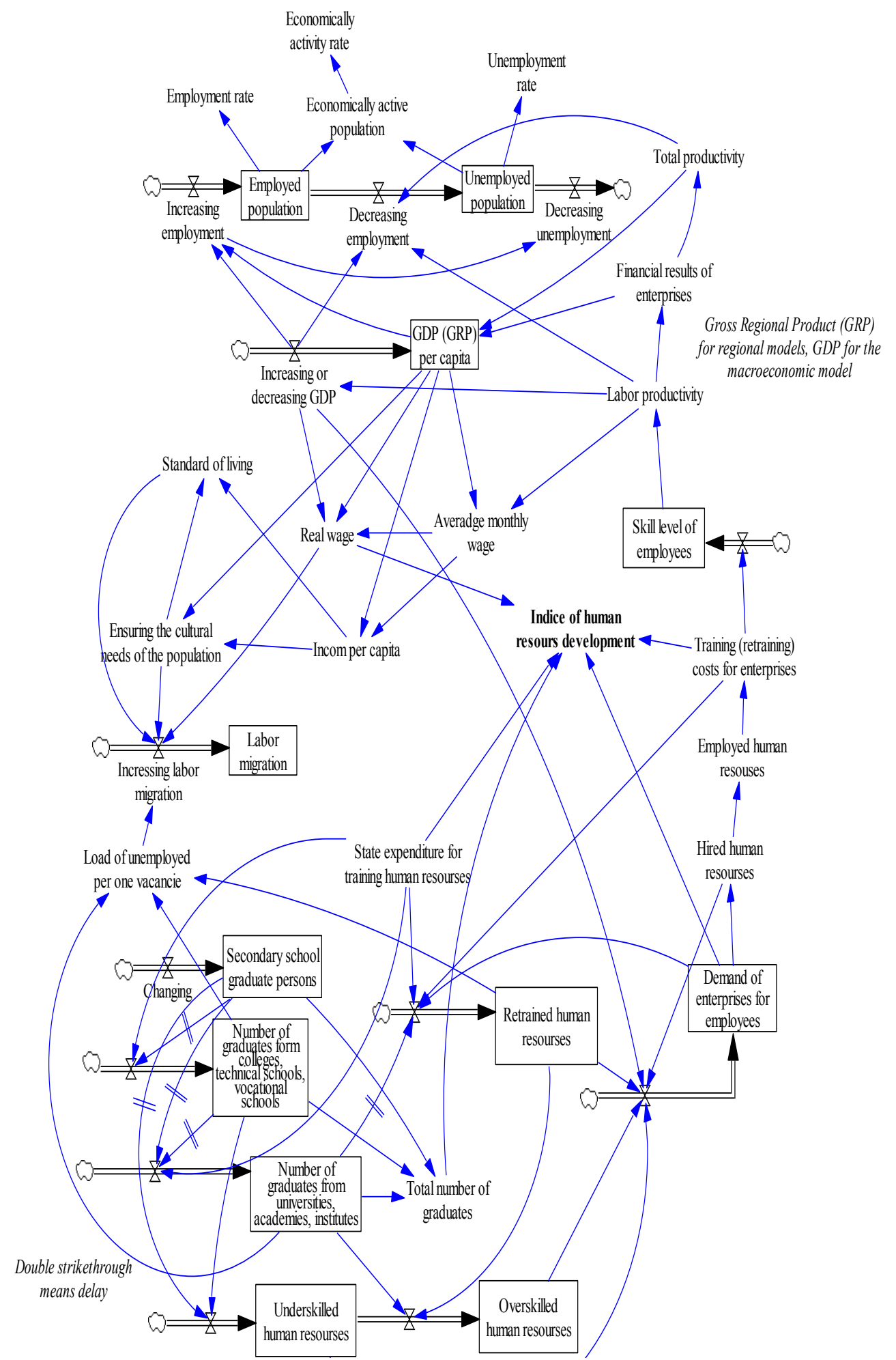

Fig. 3. Flow and a causal diagram for 3 -level model of problem-oriented development of human resources 
Table 1. Results of modelling scenarios of problem-oriented development of human resources

\begin{tabular}{|c|c|c|c|}
\hline Scenarios & Scenario parameters & $\begin{array}{l}\text { Performance for the } \\
\text { national level }\end{array}$ & $\begin{array}{l}\text { Performance at the } \\
\text { mesolevel (region, } \\
\text { united territorial } \\
\text { community (UTC)) }\end{array}$ \\
\hline 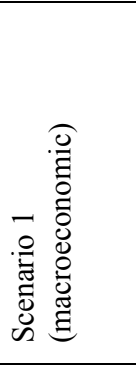 & $\begin{array}{l}\text { An increase of direct public } \\
\text { costs for education to the } \\
\text { maximum for the previous } \\
\text { years (up to } 6.78 \% \text { of GDP); } \\
\text { implementation of indirect } \\
\text { costs by stimulating the } \\
\text { professional development of } \\
\text { private entrepreneurb and } \\
\text { their employees by providing } \\
\text { a tax rebate of } 0.14 \text { points }\end{array}$ & $\begin{array}{l}1.5 \text { to } 1.7 \% \text { increase in } \\
\text { GDP per person over } \\
\text { five years compared to } \\
\text { the baseline scenario }\end{array}$ & $\begin{array}{l}\text { Increase of GRP per } \\
\text { capita by } 1.9 \% \text { on } \\
\text { average across the } \\
\text { regions as compared } \\
\text { with the baseline } \\
\text { scenario (the most one in } \\
\text { Chernivtsi Oblast }(3.1- \\
3.6 \%) \text {, the least one - in } \\
\text { the Kyiv Oblast (0.9- } \\
1.0 \%)\end{array}$ \\
\hline 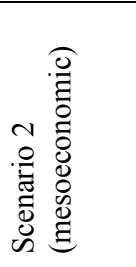 & $\begin{array}{l}\text { An increase in regional } \\
\text { budgets' costs for education by } \\
5 \% \text {, with a continuation of the } \\
\text { trend towards an increase in } \\
\text { the share of regional budgets } \\
\text { in the financing of education }\end{array}$ & $\begin{array}{l}\text { An increase in total GDP } \\
\text { by } 2.3-2.8 \% \text { over five } \\
\text { years; an increase in } \\
\text { total expenditures on } \\
\text { education by } 0.3 \text { p.p. of } \\
\text { GDP }\end{array}$ & $\begin{array}{l}\text { Increase of GRP per } \\
\text { person on average by } \\
2.3-2.8 \% \text { in the regions } \\
\text { compared to the baseline } \\
\text { scenario }\end{array}$ \\
\hline 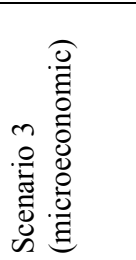 & $\begin{array}{l}\text { An increase in costs of the } \\
\text { economic entities for } \\
\text { personnel due to the costs of } \\
\text { upgrading and retraining by } \\
0.9-2.9 \% \text { on average, } \\
\text { compared with the baseline } \\
\text { scenario }\end{array}$ & $\begin{array}{l}\text { GDP growth per person } \\
\text { by } 0.56-1.1 \% \text { compared } \\
\text { to the baseline scenario }\end{array}$ & $\begin{array}{l}\text { Increase of average } \\
\text { monthly wages by } 3.7 \% \\
\text { on average }\end{array}$ \\
\hline
\end{tabular}

Thus, the modelling of problem-oriented management of territorial communities based on decentralization was carried out using the example of human resources. The results showed that the improvement of particular indicators of problem-oriented human resource management under the micro-level scenario is achieved according to the forecasts faster than under the scenarios at the meso- and macro-level. The hypothesis that the effect of measures "from below" will spread more rapidly than "from above" has been proved.

\section{References}

1. Impact of COVID-19 on the country's economy and society: Results of 2020 and challenges and threats of post-pandemic development. Consensus forecast, 53 (2021) (in Ukrainian)

2. I. Gryshova, M. Kyzym, I. Hubarieva, V. Khaustova, A. Livinskyi, M. Koroshenko, Sustainability, 12(18), (2020)

3. V.V. Krivorotov, V.G. Mokhov, O.Yu. Ivanova, O.Yu. Polyakova, Bulletin SUSU MMCS, 13(3), 68-72 (2020)

4. A.O. Shapovalova, Yu.B. Ivanov, V.F. Tyschenko, V.V. Karpova, Journal of Tax Reform, 7(1), 68-86 (2021)

5. O. Ivanova, O. Poluakova, Journal of Tax Reform, 2(1), 25-42 (2016).

6. V. Laptiev, O. Ivanova, Problem-based human resources management in the region. Coventry, United Kingdom, in Perspective directions of scientific researches:

Collection of scientific articles., 175-179 (2016). 
7. Swiss-Ukrainian Decentralization Support Project DESPRO, URL: https://despro.org.ua/en/

8. All-Ukrainian Association of United Territorial Communities, URL: https://hromady.org/pro-asociaciyu/istoriya/

9. Consequences of COVID-19 and quarantine measures for OTG. Survey results in Swiss-Ukrainian Decentralization Support Project DESPRO, URL: https://decentralization.gov.ua/uploads/attachment/document/589/COVID-19_.pdf (in Ukrainian)

10. A. O. Dvihun, Coronary crisis: new community opportunities and challenges for decentralization, URL: https://niss.gov.ua/sites/default/files/2020-06/scientificachievements-of-modern-society-niss.pdf (in Ukrainian)

11. State web portal of the budget for citizens, URL: https://openbudget.gov.ua/localbudget?id=26000000000

12. V. Laptiev, T. Stoyanova, S. Koev, P. Stoyanov, Z. Zhyvko, Academy of Strategic Management Journal, 18(3), 1-6 (2019). 